\title{
Tooth Extractions in Patients with Periodontal Diseases and Clinical Decision-Making Process
}

\section{Vađenje zuba pacijentima s parodontnim bolestima i proces donošenja kliničkih odluka}

\author{
${ }^{1}$ Department of Dentistry, Federal University of Goias, Goiania, Brazil \\ Zavod za dentalnu medicinu Federalnog sveučilišta u Goiasu, Goiania, Brazil \\ 2 Department of Therapeutic Stomatology, Institute of Dentistry, I.M. Sechenov First Moscow State Medical University, Moscow, Russian \\ Federation \\ Zavod za terapijsku dentalnu medicinu Instituta za dentalnu medicinu I. M. Sechenov Prvog moskovskog državnog medicinskog sveučilišta, \\ Moskva, Ruska Federacija \\ 3 Department of Legal Dentistry and Forensic Anthropology, Scientific Police of Goias, Goiania, Brazil \\ Zavod za pravnu dentalnu medicinu i forenzičku antropologiju Znanstvene policije u Goiasu, Goiania, Brazil
}

\section{Abstract}

Objectives: To investigate the professional aspects and clinical and radiographic evidence that influences the decision for the extraction of teeth among periodontologists and general dentists. Material and methods: The sample consisted of 150 ( $n=106$ females and 44 males) dentists ( $n=103$ general dentists and 47 periodontologists) that responded to a questionnaire designed to retrieve crosssectional information related mainly to their level of training and time of experience in practice, as well as their personal decision for managing four patients with periodontal disease. Bivariate analyses were performed to test the association between the clinical decisions and the professional information collected from the dentists. Results: In specific cases, periodontologists decided to maintain more teeth than general dentists $(p<0.05)$. In other cases, dentists with more years of experience in practice decided to opt for more extractions $(p<0.05)$. The level of periodontal disease $(50-92 \%)$, poor oral hygiene (42.6-67.3\%) and lack of alveolar bone structure (43.2-79.3\%) were the most prevalent reasons behind the decision for extractions. Conclusions: An advanced level of training in Dentistry, especially Periodontology, and more years of experience in practice may lead to more wellfounded decisions on whether extracting teeth or not in case-specific scenarios.
Received: November 19, 2018 Accepted: April 23, 2019

Address for correspondence

Rhonan Ferreira Silva

Federal University of Goiás

Department of Dentistry

Av. Universitaria, Esquina com $1^{\text {a }}$

Avenida $\mathrm{s} / \mathrm{n}$,

Goiânia, Goias, Brazil

Phone: 00556232096051

rhonansilva@gmail.com

Key words

Clinical Decision-making; Periodontics; Radiology; Tooth Extraction

\section{Introduction}

Periodontal disease is highly prevalent worldwide (1-3) and may lead to important consequences such as tooth loss (4-6). Early diagnosis and treatment founded on patient participation and plaque control contribute to better prognoses. Apart from the therapeutic approach, there is clinical evidence that plays an essential role in prognosis. Clinical attachment loss, probing depth, tooth mobility and furcation involvement are the relevant evidence of periodontal disease and as such may guide clinical decisions (7).

Additionally, dentomaxillofacial imaging has proven to be a determinant tool for treatment planning in Periodontology (8). More specifically, panoramic radiographs represent one of the most common types of dental examinations used in dental practice, thus offering an overview of the interface between the teeth and bones (9). Over the last few years, dental images have become even more important among other advances in periodontal treatment. Initially focused on pre-
Uvod

Parodontna bolest vrlo je raširena diljem svijeta $(1-3)$ i može završiti s teškim posljedicama kao što je gubitak zuba $(4-6)$. Rana dijagnoza i liječenje u suradnji s pacijentom i na temelju kontrole plaka, pridonose točnijoj prognozi. Osim terapijskog pristupa, postoje klinički pokazatelji koji su ključni u prognozi. Gubitak kliničkoga pričvrstka, dubina sondiranja, pomičnost i zahvaćenost furkacije, relevantni su pokazatelji parodontne bolesti i mogu utjecati na kliničke odluke (7).

Uz to, dokazano je da su rendgenski slikovni prikazi ključni za planiranje liječenja u parodontologiji (8). Točnije, panoramske rendgenske snimke jedne su od najčešće korištenih u stomatološkoj praksi, a daju pregled spoja između zuba i kosti (9). U posljednjih nekoliko godina dentalne rendgenske snimke dobile su još veće značenje, uz sveukupni napredak u parodontološkom liječenju. Dok se na početku parodontologija fokusirala na preventivnu skrb (10), danas se 
ventive care (10), Periodontology has entered the spotlight of complex therapeutics that includes tissue regeneration, improvement of systemic conditions and oral rehabilitation (11).

The scientific progress that has occurred in dentomaxillofacial imaging and Periodontology has benefited clinical performance but also culminated in a broad range of available therapeutic options. Deciding between these options has become a challenging task for dentists and patients. Professional training in the field, clinical experience and the patient's socioeconomic condition are ranked among the decisionmaking factors in the scientific literature (12-14). Based on the hypothesis that radiographic exams contribute to the decision-making process and that several factors may influence the therapeutic approach in Periodontology, this study aimed to assess the decisions of dentists for maintaining or extracting teeth in patients with periodontal disease.

\section{Material and methods}

\section{Study design}

A quantitative questionnaire-based cross-sectional and observational study was designed and conducted after the approval of the local Committee of Ethics in Human Research (protocol: 64611317.6.0000.5083). naglasak stavlja na složene terapije koje uključuju regeneraciju tkiva, poboljšanje sustavnih stanja i oralnu rehabilitaciju (11).

Znanstveni napredak koji se dogodio u slikovnim prikazima i parodontologiji pogodovao je kliničkoj izvedbi, ali je također kulminirao širokim rasponom dostupnih terapijskih mogućnosti. Odluka između tih opcija postala je izazovan zadatak za terapeute i pacijente. Stručno usavršavanje na terenu, kliničko iskustvo i socijalno-ekonomski status pacijenta, u znanstvenoj su literaturi svrstani među čimbenike bitne za odlučivanje $(12-14)$. Na temelju hipoteze da rendgenski pregled pomaže u procesu odlučivanja i da nekoliko čimbenika može utjecati na terapijski pristup u parodontologiji, cilj ovog istraživanja bio je procijeniti odluke doktora za očuvanje ili vađenje zuba pacijentima s parodontnom bolesti.

\section{Materijali i metode}

\section{Studijski dizajn}

Osmišljeno je i provedeno kvantitativno opservacijsko istraživanje poprečnog presjeka na temelju upitnika, a nakon odobrenja Odbora za etiku u istraživanjima na ljudima (protokol: 64611317.6.0000.5083).
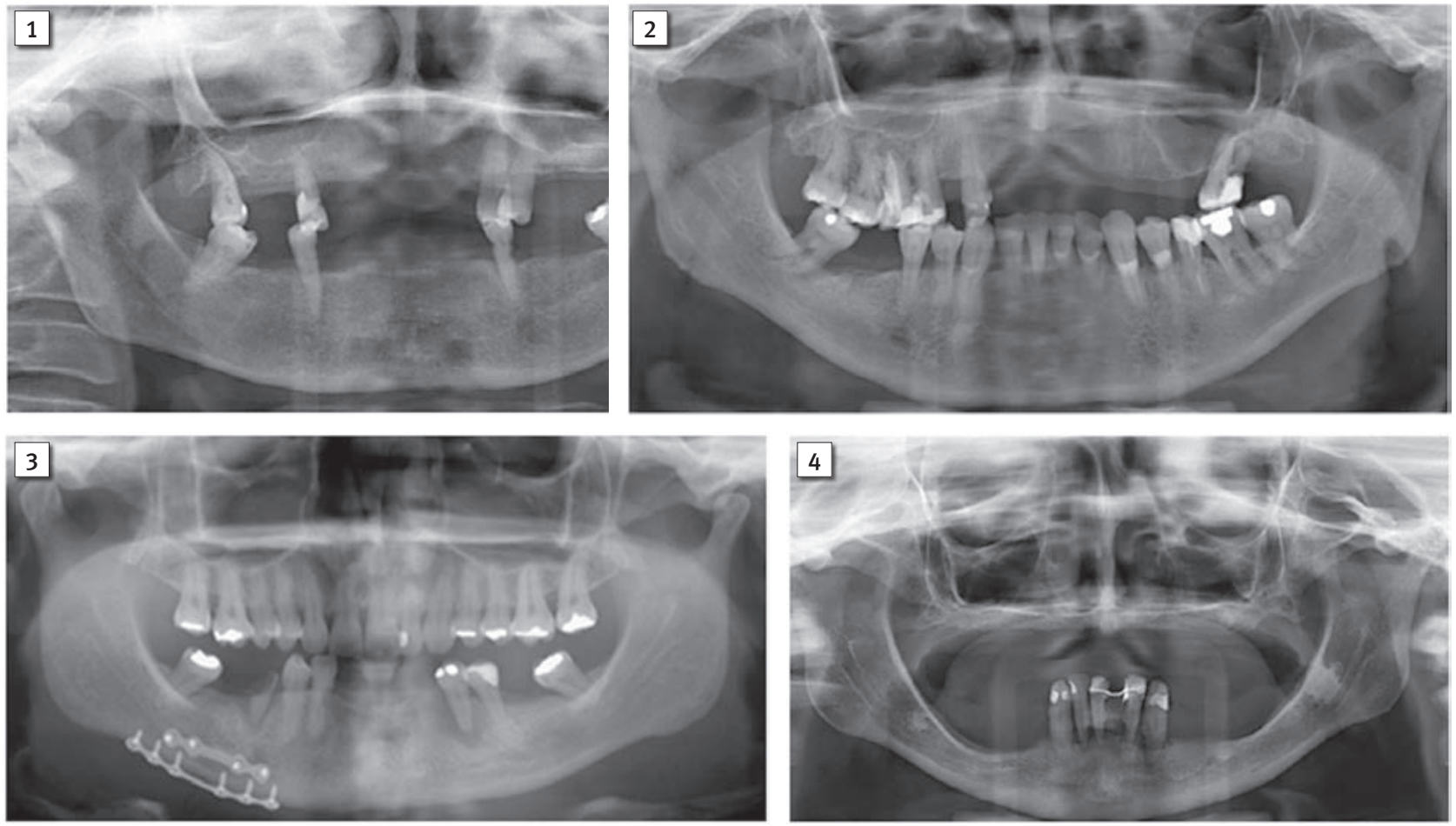

Figure 1 Panoramic radiograph of the patient presented in case \#1 Slika 1. Panoramska snimka pacijenta 1

Figure 2 Panoramic radiograph of the patient presented in case \#2

Slika 2. Panoramska snimka pacijenta 2

Figure 3 Panoramic radiograph of the patient presented in case \#3

Slika 3. Panoramska snimka pacijenta 3

Figure 4 Panoramic radiograph of the patient presented in case \#4

Slika 4. Panoramska snimka pacijenta 4 


\section{Setting and Participants}

The target sample consisted of general dentists (Group 1) and periodontologists (Group 2) of Goiânia - a capital city in Central Brazil. The inclusion criteria for Group 1 consisted of dentists registered at the State Council of Dentistry AND (that work within general dentistry OR any other specialty different than Periodontology), In Group 2, the inclusion criterion consisted of dentists properly registered as specialists in Periodontology at the State Council of Dentistry. In both groups, the exclusion criterion consisted of dentists with professional practice outside the capital city. During sampling, 423 general dentists and 84 periodontologists were reached in their dental offices, professional meetings and in training courses.

\section{Variables}

The dentists reached in the sampling phase received softor hard-copies of an adapted questionnaire (15). Question-

\section{Postavke i sudionici}

Ciljni uzorak činili su opći stomatolozi (skupina 1) i parodontolozi (skupina 2) iz Goiânije - glavnoga grada srednjeg Brazila. U prvu skupinu bili su uključeni stomatolozi prijavljeni u Državnom vijeću za stomatologiju I (koji djeluju u sklopu opće stomatologije ILI bilo koje druge specijalnosti različite od parodontologije), a u drugu skupinu stomatolozi koji su registrirani kao specijalisti za parodontologiju u Državnom vijeću za stomatologiju. U objema skupinama isključni kriteriji bili su stomatolozi s profesionalnom praksom izvan glavnoga grada. Tijekom uzorkovanja bila su uključena 423 opća stomatologa i 84 parodontologa u njihovim stomatološkim ordinacijama, na stručnim sastancima i na tečajevima osposobljavanja.

\section{Varijable}

Uključeni doktori dentalne medicine dobili su meke ili tvrde kopije prilagođenog upitnika (15). Upitnici su osmi-

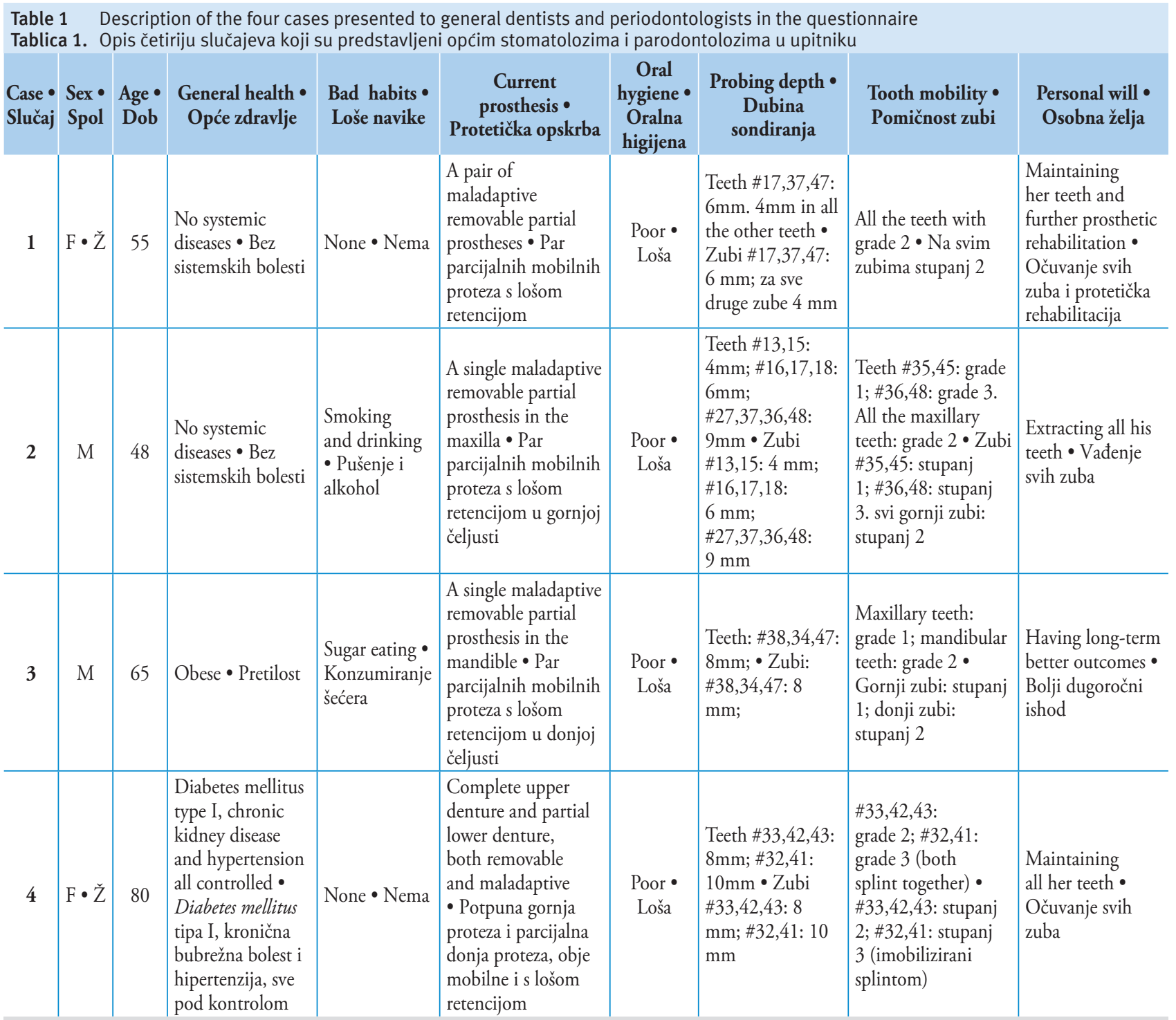

F: female; M: male; age expressed in years and probing depth representative for all tooth surfaces. Cases \#1, 2, 3 and 4 are illustrated in Figures 1, 2, 3 and 4, respectively. Dental coding according to the International Dental Federation.

Ž: ženski; M: muški; dob izražena u godinama i dubina sondiranja reprezentativna za sve zubne plohe; slučajevi \#1, 2, 3 i 4 ilustrirani su na slikama 1 , 2., 3. i 4.; kodiranje zubi prema FDI-u. 
naires were designed to retrieve personal information from each dentists, such as, gender, age, field of practice (periodontologist or not), years of experience in practice and the type of undergraduate program (public or private). Additionally, four cases were presented to the dentists (Figures 1-4). Each of the cases had a brief description and a panoramic radiograph (Table 1).

\section{Data measurements}

After reading the clinical cases, the dentists were required to provide their decision for treating each patient. Four options were offered to manage the remaining teeth of each patient: I) maintaining all the teeth; II) extracting 3 teeth or less; III) extracting more than 3 teeth; and IV) extracting all the teeth. To those who decided for extractions, additional justifications were requested. The available justifications were: a) the severity of periodontal disease, b) the lack of alveolar bone structure; c) poor oral hygiene; d) the cost-benefit relation; e) few teeth remaining; f) easiness to designing prostheses; g) esthetics needs; and h) the patient's personal will. The dentists were free to provide justifications based on one or more options.

\section{Statistical methods}

The data was analyzed with descriptive statistics of the absolute and relative frequencies of the quantified decision of dentists who were for tooth extractions or against them. The Chi-square test and the Pearson's correlation coefficient were used to assess the potential association between decisions for dental extractions according to the level of education and training of dentists (Periodontology or not), their time of experience in practice (expressed in years) and their type of undergraduate program (public or private). The statistical analyses were performed using the IBM SPSS 24.0 software package (IBM Crop., Armonk, New York, USA). The significance level was set at $5 \%$.

\section{Results}

The questionnaire was reponded by $150(35.5 \%)$ dentists, out of which $103(68.7 \%)$ general dentists and 47 $(31.3 \%)$ were Periodontologists. In total, forty-four (29.3\%) dentists were males and $106(70.7 \%)$ were females. Onehundred and two dentists $(70.3 \%)$ were aged below 30 years and $43(29.7 \%)$ were older than 30 years of age. Most of the dentists $(\mathrm{n}=123 ; 82 \%)$ had less than 15 years of experience in practice.

In case \#1 (Figure 1), sixty-three (42\%) and 84 (56\%) dentists decided for maintaining all the maxillary and mandibular teeth, respectively. In case \#2 (Figure 2), most of the dentists decided for the extraction of less than 3 teeth in the maxillary $(\mathrm{n}=86 ; 57.3 \%)$ and in the mandibular arches $(\mathrm{n}=139 ; 92.7 \%)$. In case \#3 (Figure 3), seventy-two (48\%) dentists decided for the extraction of less than three teeth in the mandibular arch. In case \#4 (Figure 4), most of the dentists $(n=125 ; 83.3 \%)$ decided for the extraction of all the teeth, while only 7 (4.7\%) decided the opposite (maintaining all the teeth) (Table 2).

Statistically significant associations were observed between the clinical decision in case \#1 and the level of edu- šljeni za prikupljanje osobnih podataka svakog ispitanika, kao što su spol, dob, specijalnost (parodontolog ili ne), godine iskustva u praksi i vrsta preddiplomskog studija (javni ili privatno fakultet). Uz to, doktorima su predočena četiri klinička slučaja (slike 1. - 4.) s kratkim opisom i panoramskom rendgenskom snimkom (tablica 1.).

\section{Prikupljanje podataka}

Nakon čitanja opisa kliničkih slučajeva, doktori su morali donijeti svoju terapijsku odluku za svakog pacijenta. Bile su ponuđene četiri opcije: 1 . održavanje svih zuba, 2. vađenje tri zuba ili manje, 3 . vađenje više od tri zuba, 4 . vađenje svih zuba.

Od onih koji su se odlučili za vađenje, zatražena su dodatna obrazloženja. Najčešća opravdanja bila su: a) ozbiljnost parodontne bolesti, b) nedostatak alveolarne kosti, c) loša oralna higijena, d) odnos troškova i koristi, e) malo preostalih zuba, f) jednostavnost izrade proteze, g) estetske potrebe, h) pacijentova osobna volja. Pacijenti su mogli odabrati jednu ili više opcija.

\section{Statističke metode}

Podatci su analizirani deskriptivnom statistikom apsolutnih i relativnih učestalosti kvantificirane odluke stomatologa koji su bili za ili protiv vađenja zuba. Hi-kvadrat test i Pearsonov koeficijent korelacije korišteni su za procjenu potencijalne povezanosti odluka za ekstrakciju zuba prema stupnju obrazovanja i osposobljenosti stomatologa (parodontolog ili ne), njihova iskustva u praksi (izraženo u godinama) i vrsti preddiplomskog studija (javni ili privatni). Statističke analize obavljene su programskim paketom IBM SPSS 24.0 (IBM Crop., Armonk, New York, SAD). Razina značajnosti bila je postavljena na $5 \%$.

\section{Rezultati}

Upitnik je ispunilo $150(35,5 \%)$ doktora dentalne medicine, od kojih 103 (68,7 \%) opća i 47 (31,3\%) parodontologa. Četrdeset i četiri $(29,3 \%)$ doktora bili su muškarci, a $106(70,7 \%)$ bile su žene. Stotinjak doktora (70,3 \%) bilo je mlađe od 30 godina, a $43(29,7 \%)$ u dobi iznad 30 godina. Većina $(n=123 ; 82 \%)$ je imala manje od 15 godina iskustva u praksi.

Kod slučaja 1 (slika 1.), 63 (42\%) i 84 (56\%) doktora odlučilo se za održavanje svih zuba u gornjoj i donjoj čeljusti. Kod slučaja 2 (slika 2.), većina doktora odlučila se za vađenje manje od tri zuba u gornjoj $(\mathrm{n}=86 ; 57,3 \%)$ i u donjoj čeljusti ( $\mathrm{n}=139$; 92,7\%). Kod slučaja 3 (slika 3.), 72 (48 \%) doktora odlučila su izvaditi manje od tri zuba u donjoj čeljusti. Kod slučaja 4 (slika 4.), većina doktora $(n=125 ; 83,3 \%)$ odlučila se za vađenje svih zuba, a samo 7 (4,7 \%) odabralo je suprotno (očuvanje svih zubi) (tablica 2.).

Uočena je statistički značajna povezanost između kliničke odluke u slučaju 1 i stupnja obrazovanja i osposobljenosti doktora $(\mathrm{p}<0,05)$. Točnije, parodontolozi su se češće odlučivali za očuvanje zuba (tablica 3.). U slučajevima 2 i 3 , iskustvo u praksi imalo je važnu ulogu u donošenju kliničkih 
cation and training of the dentists $(\mathrm{p}<0.05)$. More specifically, periodontologists decided more often for maintaining the teeth (Table 3). In cases \#2 and 3, time of experience in practice played a significant role in clinical decision making $(\mathrm{p}<0.05)$. More experienced dentists decided for more extractions (Tables 4 and 5). In case \#4, the association did not result in statistical significance ( $p>0.05$, Table 6). Statistically significant associations were observed between the level of education and training and the time of experience in practice odluka $(\mathrm{p}<0,05)$. Iskusniji doktori odlučili su se za dodatna vađenja (tablice 4. i 5.). U slučaju 4 , povezanost nije bila statistički značajna ( $p>0,05$, tablica 6.). Uočena je statistički značajna povezanost između razine obrazovanja i osposobljenosti i iskustva u praksi $(\mathrm{p}<0,05)$. Većina parodontologa imala je više iskustva, a većina općih stomatologa manje $(\mathrm{p}=0,001)$.

Ozbiljnost parodontne bolesti, nedostatak alveolarne kosti i loša higijena smatrali su se najčešćim razlozima kojima su

Table 2 Absolute and relative frequencies of clinical decisions for extractions in the maxilla and mandible

Tablica 2. Apsolutne i relativne frekvencije kliničke odluke o vađenju zuba u gornjoj i donjoj čeljusti

\begin{tabular}{|c|c|c|c|c|c|c|c|}
\hline \multirow[b]{2}{*}{ Decision • Odluka } & \multicolumn{2}{|c|}{ Case \#1 • Slučaj 1} & \multicolumn{2}{|c|}{ Case \#2・Slučaj 2} & \multicolumn{2}{|c|}{ Case \#3・ Slučaj 3} & \multirow{2}{*}{$\begin{array}{c}\text { Case \#4 • Slučaj } 4 \\
\text { Mandible } \\
\text { Mandibula }\end{array}$} \\
\hline & $\begin{array}{c}\text { Maxilla • } \\
\text { Maksila }\end{array}$ & $\begin{array}{l}\text { Mandible • } \\
\text { Mandibula }\end{array}$ & $\begin{array}{c}\text { Maxilla • } \\
\text { Maksila }\end{array}$ & $\begin{array}{l}\text { Mandible } \\
\text { Mandibula }\end{array}$ & $\begin{array}{c}\text { Maxilla } \\
\text { Maksila }\end{array}$ & $\begin{array}{l}\text { Mandible • } \\
\text { Mandibula }\end{array}$ & \\
\hline Maintaining $\bullet$ Očuvanje & $42 \%(63)$ & $56 \%(84)$ & $4.7 \%(7)$ & $4 \%(6)$ & $98 \%(147)$ & $8.7 \%(13)$ & $4.7 \%(7)$ \\
\hline$<3$ extractions $\bullet<3$ vađenja & $32.7 \%(49)$ & $22 \%(33)$ & $57.3 \%(86)$ & $92.7 \%(139)$ & $0.7 \%(1)$ & $48 \%(72)$ & $11.3 \%(17)$ \\
\hline$>3$ extractions $\bullet>3$ vađenja & $9.3 \%(14)$ & $6 \%(9)$ & $36 \%(54)$ & $1.3 \%(2)$ & $0 \%(0)$ & $18.7 \%(28)$ & $0.7 \%(1)$ \\
\hline Extract all $\bullet$ Vađenje svih zuba & $14.7 \%(22)$ & $14.7 \%(22)$ & $2 \%(3)$ & $2 \%(3)$ & $0 \%(0)$ & $23.3 \%(35)$ & $83.3 \%(125)$ \\
\hline
\end{tabular}

Cases \#1, 2, 3 and 4 are illustrated in Figures 1,2, 3 and 4, respectively. • Slučajevi 1, 2, 3 i 4 ilustrirani su na slikama 1., 2., 3. i 4.

Table 3 Comparison between the level of education and training, time of experience in practice and type of undergraduation program and the decision for extractions or not in case \#1

Tablica 3. Usporedba između razine edukacije, iskustva u praksi i vrsti dodiplomskog studija na odluku o vađenju za slučaj 1

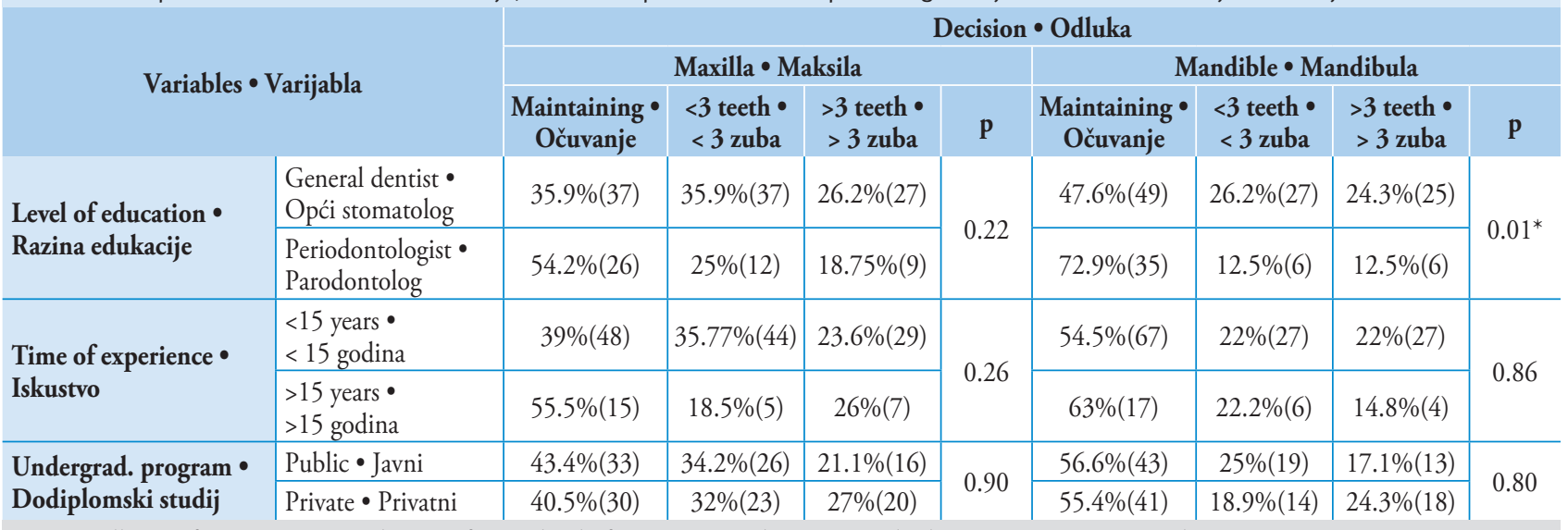

*Statistically significant outcome with a significance level of $5 \%$. Statistički značajan ishod $s$ razinom značajnosti od $5 \%$.

Table 4 Comparison between the level of education and training, time of experience in practice and type of undergraduation program and the decision for extractions or not in case \#2

Tablica 4. Usporedba između razine edukacije, iskustva u praksi i vrsti dodiplomskog studija na odluku o vađenju za slučaj 2

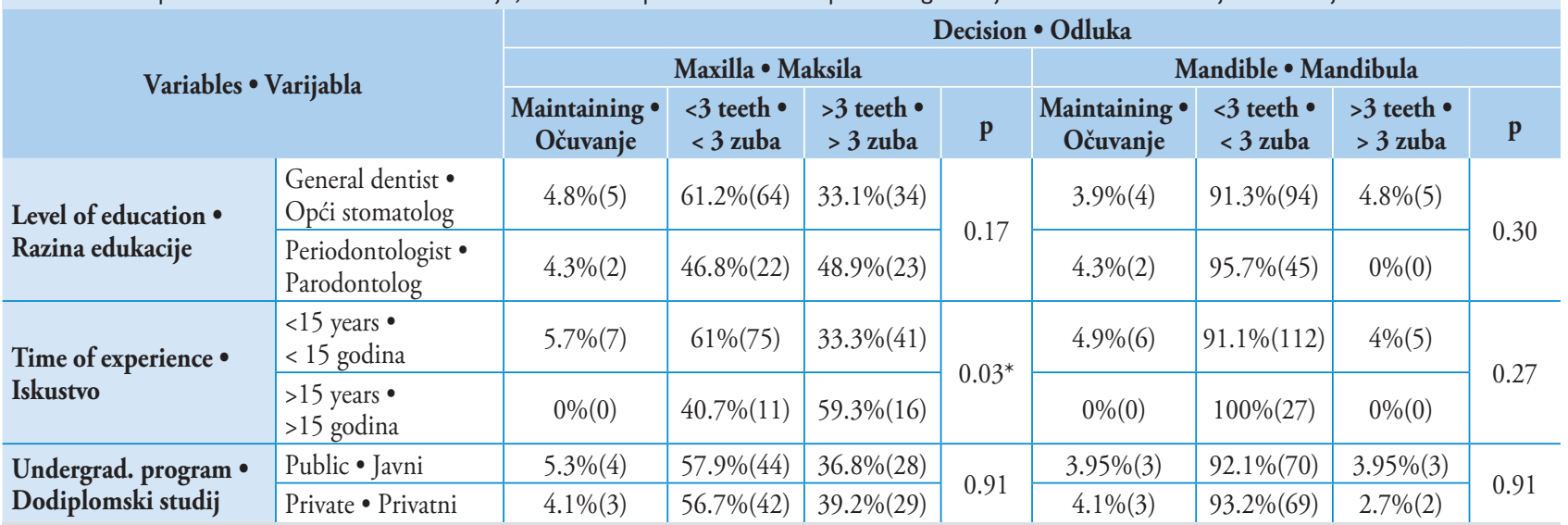

*Statistically significant outcome with a significance level of $5 \%$. Statistički značajan ishod $s$ razinom značajnosti od $5 \%$. 
Table 5 Comparison between the level of education and training, time of experience in practice and type of undergraduation program and the decision for extractions or not in case \#3

Tablica 5. Usporedba između razine edukacije, iskustva u praksi i vrsti dodiplomskog studija na odluku o vađenju za slučaj 3

\begin{tabular}{|c|c|c|c|c|c|c|c|c|c|}
\hline \multirow{3}{*}{\multicolumn{2}{|c|}{ Variables $\bullet$ Varijabla }} & \multicolumn{8}{|c|}{ Decision • Odluka } \\
\hline & & \multicolumn{4}{|c|}{ Maxilla $\bullet$ Maksila } & \multicolumn{4}{|c|}{ Mandible $\bullet$ Mandibula } \\
\hline & & $\begin{array}{c}\text { Maintaining • } \\
\text { Očuvanje }\end{array}$ & $\begin{array}{l}<3 \text { teeth } \\
<3 \text { zuba }\end{array}$ & $\begin{array}{l}>3 \text { teeth } \\
>3 \text { zuba }\end{array}$ & p & $\begin{array}{c}\text { Maintaining • } \\
\text { Očuvanje }\end{array}$ & $\begin{array}{l}<3 \text { teeth } \\
<3 \text { zuba }\end{array}$ & $\begin{array}{l}>3 \text { teeth } \\
>3 \text { zuba }\end{array}$ & $\mathbf{p}$ \\
\hline \multirow{2}{*}{$\begin{array}{l}\text { Level of education • } \\
\text { Razina edukacije }\end{array}$} & $\begin{array}{l}\text { General dentist } \\
\text { Opći stomatolog }\end{array}$ & $98.05 \%(101)$ & $0 \%(0)$ & $0 \%(0)$ & \multirow{2}{*}{0.14} & $8.7 \%(9)$ & $52.4 \%(54)$ & $36.9 \%(38)$ & \multirow{2}{*}{0.18} \\
\hline & $\begin{array}{l}\text { Periodontologist } \\
\text { Parodontolog }\end{array}$ & $97.9 \%(46)$ & $2.1 \%(1)$ & $0 \%(0)$ & & $8.5 \%(4)$ & $38.3 \%(18)$ & $53.2 \%(25)$ & \\
\hline \multirow{2}{*}{$\begin{array}{l}\text { Time of experience } \\
\text { Iskustvo }\end{array}$} & $\begin{array}{l}<15 \text { years } \bullet \\
<15 \text { godina }\end{array}$ & $99.2 \%(122)$ & $0 \%(0)$ & $0 \%(0)$ & \multirow{2}{*}{$0.03^{*}$} & $9.8 \%(12)$ & $51.2 \%(63)$ & $38.2 \%(47)$ & \multirow{2}{*}{$0.09^{*}$} \\
\hline & $\begin{array}{l}>15 \text { years } \bullet \\
>15 \text { godina }\end{array}$ & $92.6 \%(25)$ & $3.8 \%(1)$ & $0 \%(0)$ & & $3.7 \%(1)$ & $33.3 \%(9)$ & $59.3 \%(16)$ & \\
\hline \multirow{2}{*}{$\begin{array}{l}\text { Undergrad. program • } \\
\text { Dodiplomski studij }\end{array}$} & Public $\bullet J a v n i$ & $100 \%(76)$ & $0 \%(0)$ & $0 \%(0)$ & \multirow{2}{*}{0.30} & $10.6 \%(8)$ & $44.7 \%(34)$ & $44.7 \%(34)$ & \multirow{2}{*}{0.54} \\
\hline & Private $\bullet$ Privatni & $95.9 \%(71)$ & $1.4 \%(1)$ & $0 \%(0)$ & & $6.7 \%(5)$ & $51.3 \%(38)$ & $39.1 \%(29)$ & \\
\hline
\end{tabular}

*Statistically significant outcome with a significance level of $5 \%$. Statistički značajan ishod s razinom značajnosti od $5 \%$.

\begin{tabular}{|c|c|c|c|c|c|}
\hline & \multirow{3}{*}{ Variables $\bullet$ Varijabla } & \multicolumn{4}{|c|}{ Decision $\bullet$ Odluka } \\
\hline & & \multicolumn{4}{|c|}{ Mandible $\bullet$ Mandibula } \\
\hline & & $\begin{array}{l}\text { Maintaining • } \\
\text { Očuvanje }\end{array}$ & $<3$ teeth $\bullet<3$ zuba & $>3$ teeth $\bullet>3$ zuba & p \\
\hline \multirow{2}{*}{$\begin{array}{l}\text { Level of education } \\
\text { Razina edukacije }\end{array}$} & General dentist • Opći stomatolog & $3.9 \%(4)$ & $10.7 \%(11)$ & $85.4 \%(88)$ & \multirow{2}{*}{0.72} \\
\hline & Periodontologist $\bullet$ Parodontolog & $6.4 \%(3)$ & $12.8 \%(6)$ & $80.8 \%(38)$ & \\
\hline \multirow{2}{*}{$\begin{array}{l}\text { Time of experience } \\
\text { Iskustvo }\end{array}$} & $<15$ years $\bullet<15$ godina & $4.9 \%(6)$ & $13 \%(16)$ & $82.1 \%(101)$ & \multirow{2}{*}{0.68} \\
\hline & $>15$ years $\bullet>15$ godina & $3.7 \%(1)$ & $7.4 \%(2)$ & $88.9 \%(24)$ & \\
\hline \multirow{2}{*}{$\begin{array}{l}\text { Undergrad. program } \\
\text { Dodiplomski studij }\end{array}$} & Public $\bullet$ Javni & $5.3 \%(4)$ & $11.8 \%(9)$ & $82.9 \%(63)$ & \multirow{2}{*}{0.91} \\
\hline & Private $\bullet$ Privatni & $4.1 \%(3)$ & $10.8 \%(8)$ & $85.1 \%(63)$ & \\
\hline
\end{tabular}

$(\mathrm{p}<0.05)$. I.e. Most of the periodontologists had more experience, while most of general dentists had less time of experience $(\mathrm{p}=0.001)$.

The severity of periodontal disease, the lack of alveolar bone structure and poor hygiene figured as the most prevalent reasons that justified the decisions for extractions. The severity of periodontal disease reached a prevalence of $50 \%$, $92 \%, 83.3 \%$ and $86 \%$ in cases \#1, 2, 3 and 4, respectively. The lack of alveolar bone structure reached $43.2 \%, 59.3 \%$, $50.7 \%$ and $79.3 \%$, in the same cases, while poor hygiene reached $42.6 \%, 67.3 \%, 43.3 \%$ and $60 \%$.

\section{Discussion}

Periodontal disease may be manifested as destruction of tooth-supporting tissue (16) and may culminate within functional and esthetic damage to affected patients (17). In the new era of scientific development, the decision for extracting teeth with periodontal disease is a challenging task, especially because many therapeutic alternatives are available in dentistry, such as tissue regeneration biomaterials (18). Recent studies have demonstrated how positive is the prognosis of teeth maintained and treated. In a recent systematic literature review (19), the survival rate of periodontally affected teeth was compared to the survival rate of dental implants. The authors se opravdavale odluke o vađenju. Težina parodontne bolesti dosegnula je prevalenciju od $50 \%, 92 \%, 83,3 \%$ i $86 \%$ u slučajevima $1,2,3$, odnosno 4 . U istim slučajevima nedostatak alveolarne kosti iznosio je 43,2 \%, 59,3 \%, 50,7 \% i 79,3 $\%$, a loša higijena dosezala je 42,6 \%, 67,3 \%, 43,3 \% i $60 \%$.

\section{Rasprava}

Parodontna bolest manifestira se razaranjem tkiva koje podupire zube (16) i može kulminirati funkcijskim i estetskim oštećenjem pogođenih pacijenata (17). Danas, u doba znanstvenog razvoja, odluka o vađenju zuba s parodontnom bolešću izazovan je zadatak, posebno zato što su dostupne mnoge alternative, kao što su biomaterijali za regeneraciju tkiva (18). Nedavno istraživanje pokazalo je koliko je povoljna prognoza za očuvane i tretirane zube. $U$ aktualnom sistematiziranom pregledu literature (19), stopa preživljavanja parodontno kompromitiranih zuba uspoređena je sa stopom preživljavanja dentalnih implantata. Autori su pokazali 
showed that patients undergoing optimal therapeutics had a tooth survival rate which is not inferior to the survival rate of implants. These outcomes suggest that extractions followed by implant rehabilitation should be considered as case-specific. In other words, patients with previous periodontal disease may evolve into patients with peri-implant disease (20).

In the first case, the patient had moderate general chronic periodontitis. The dentists mostly took a conservative approach. Their decision for maintaining the maxillary (42\%) and mandibular teeth $(56 \%)$ was probably influenced by the lower severity of the disease compared to other cases. From a periodontal point of view, these teeth could be maintained and treated with a good prognosis. For those who opted for extractions, a combination of factors seems to have influenced their decision such as poor oral hygiene and a lack of alveolar bone structure. It is important to note that the costbenefit relation justified the decision for the extractions in $30.4 \%$ of the cases. However, the scientific literature shows that periodontal treatment may have a better cost-benefit relationship when compared to extractions followed by rehabilitation with implants and prostheses (21-23). Furthermore, a deeper look into the first case showed statistically significant differences between periodontologists and general dentists. Decisions for fewer extractions were made by periodontologists, while general dentists took more invasive approaches. These outcomes show the important role of education and training in dentistry in order to opt for more conservative therapeutic approaches $(12,15)$.

In the second case, the patient had generalised advanced chronic periodontitis. Despite the advanced disease, the patients had more teeth compared to those in the first case. Grade 3 tooth mobility, the exposure of the root bifurcation and smoking and drinking habits played a big role in a bad prognosis $(24,25)$. Most of the dentists decided to extract less than 3 teeth in the maxillary (57.3\%) and mandibular (92.7\%) arches. Interestingly, 2\% of the dentists decided to extract all of the teeth (including those able to be maintained with periodontal treatment), a decision not supported by the scientific literature. The popularisation and availability of dental implants have made extractions more prevalent and the alternative choice for patients that want short-term solutions. In this context, the number of teeth recommended for extractions was associated with the time of experience in practice $(\mathrm{p}<0.05)$. Dentists with more than 15 years of experience in practice opted to extract a larger number of teeth. In general, these dentists were mostly periodontologists, and due to their personal experience with similar cases, they could predict a lack of success under the described intraoral conditions and the additional smoking and drinking habits reported by the patient.

In the third case, the patient had a stable periodontal condition in the maxillary teeth but periodontitis in the mandibular teeth. Differently, the patient was more demanding about the treatment time and longevity. In the maxillary arch, only a single dentist decided to extract teeth \#17 and 27. In the mandibular arch, most of the dentists (48\%) decided to extract less than 3 teeth. The severity of the periodontal disease $(83.3 \%)$ and the lack of alveolar bone structure $(50.7 \%)$ da pacijenti koji se podvrgavaju optimalnim terapijama imaju stopu preživljavanja zuba koja nije niža od stope preživljavanja implantata. Ti rezultati upućuju na to da vađenje zuba i rehabilitaciju implantatima treba, kod nekih pacijenata, smatrati specifičnom terapijom. Drugim riječima, pacijenti s parodontnom bolešću mogu se razviti u pacijente s periimplantantnom bolešću (20).

U prvom slučaju pacijent je imao umjereni opći kronični parodontitis. Doktori su uglavnom smatrali da je potreban konzervativni pristup. Na njihovu odluku o očuvanju maksilarnih (42\%) i mandibularnih zuba (56\%) vjerojatno je utjecala manja ozbiljnost bolesti u usporedbi s drugim slučajevima. $S$ parodontološkog stajališta, ti se zubi mogu očuvati i liječiti, a prognoza je dobra. Kod onih koji su se odlučili za vađenje, čini se da je na njihovu odluku utjecala kombinacija loše oralne higijene i nedostatak alveolarne kosti. Važno je napomenuti da je odnosom troškova i koristi obrazložena odluka o vađenju u 30,4\% slučajeva. No znanstvena literatura pokazuje da se parodontološkim liječenjem može postići bolji odnos troškova i koristi u usporedbi s vađenjem, nakon čega slijedi rehabilitacija s implantatima i protezama (21 -23). Nadalje, detaljnija analiza prvog slučaja pokazala je statistički značajne razlike između parodontologa i općih stomatologa. Odluke o manje vađenja donosili su parodontolozi, a opći stomatolozi imali su invazivniji pristup. Ti rezultati pokazuju koliko je važno obrazovanje i osposobljavanje u dentalnoj medicini kako bi se odabrali konzervativniji terapijski pristupi $(12,15)$.

U drugom slučaju, pacijent je imao generalizirani napredni kronični parodontitis. Unatoč napredovaloj bolesti, imao je više zuba u usporedbi s onima u prvom slučaju. Mobilnost zuba trećeg stupnja, izloženost bifurkacije korijena te pušenje i konzumiranje alkohola, imali su veliku ulogu u lošoj prognozi $(24,25)$. Većina doktora odlučila je izvaditi manje od tri zuba u gornjoj (57,3\%) i donjoj (92,7 \%) čeljusti. Zanimljivo je da je $2 \%$ doktora odlučilo izvaditi sve zube (uključujući i one koji se mogu očuvati uz liječenje parodonta), što nije potvrđeno u znanstvenoj literaturi. Popularizacija i dostupnost zubnih implantata učinili su vađenje zuba glavnim izborom za pacijente koji žele brza rješenja. U tom kontekstu, broj preporučenih zuba za vađenje bio je povezan $s$ iskustvom u praksi $(\mathrm{p}<0,05)$. Doktori s više od 15 godina iskustva odlučili su izvaditi veći broj zuba. Općenito, ti doktori dentalne medicine uglavnom su bili parodontolozi, a zbog svojega osobnog iskustva sa sličnim slučajevima mogli su predvidjeti neuspjeh s obzirom na opisane intraoralne uvjete i dodatne loše navike pušenja i konzumiranja alkohola.

U trećem slučaju pacijent je imao stabilno stanje parodonta na gornjim zubima, ali parodontitis na donjim zubima. Drugim riječima, bio je zahtjevniji kad je riječ o trajanju liječenja i dugoročnom ishodu. U gornjoj čeljusti samo je jedan doktor odlučio izvaditi zube 17 i 27 . U donjoj čeljusti većina njih (48\%) odlučila je izvaditi manje od tri zuba. Težina parodontne bolesti $(83,3 \%)$ i nedostatak alveolarne kosti $(50,7 \%)$ bili su najčešći razlozi za odluke o vađenju. Ti rezultati pokazuju da su klinički aspekti bolesti relevantni čimbenici u odlučivanju treba li izvaditi zub ili ne. Parodontolozi vjerojatno donose bolje utemeljene odluke o vađenju jer bolje 
were the most prevalent reasons behind the decisions for extractions. These outcomes show that the clinical aspects of the disease are relevant factors for deciding on whether to extract or not. Periodontologists may be more well-founded when deciding on extractions as they have a better understanding of the clinical evidence of periodontal disease. This fact is confirmed with the association of the time of experience in practice and the number of extractions, which shows that periodontologists may indicate more extractions in specific cases because of their knowledge and experience in the field.

In the fourth case, the patient had no teeth in the maxillary arch and poorly supported teeth in the mandible. In spite of the fact that a periodontal treatment was carried out (surgical or not), a bad prognosis was expected. Most of the dentists (83.3\%) opted to extract all of the teeth. Those who decided to maintain the teeth could be supported by the Bioethics' principle of autonomy (26), which lets the patient participate in the clinical decision process (the patient wanted to maintain her teeth). The severity of the periodontal disease (86\%), a lack of alveolar bone structure $(79.3 \%)$ and poor oral hygiene $(60 \%)$ were the most prevalent reasons that led to the decision for extractions. These factors in association with the patient's age and her clinical condition could justify the decision for extractions.

As in most of the questionnaire-based surveys, this study was designed to simulate a clinical scenario with four cases to investigate and illustrate the decision-making process in periodontology. Future studies should be structured to investigate more specifically the level of knowledge in periodontology and its influence in deciding on more complex and more detailed clinical cases. Additionally, the developed questionnaire should be tested and validated in other populations in order to have a broader range of data collected and to enable population-specific comparisons in the future.

\section{Conclusion}

Regarding tooth extractions, the clinical decision-making process made by general dentists and periodontologists was influenced by the level of periodontal disease, the level of oral hygiene of the patient and the level of the remaining alveolar bone.

As expected, case-specific circumstances influenced on the clinical decision-making process, but in most of the cases periodontologists were less invasive and decided more often to maintain the teeth with proper therapeutic follow-up.

\section{Conflict of interest}

The authors report no conflict of interest. razumiju kliničke pokazatelje parodontne bolesti. Tu činjenicu potvrđuje povezanost iskustva u praksi i broja vađenja, što je pokazalo da se parodontolozi mogu odlučiti za više vađenja u određenim slučajevima zbog svojeg znanja i iskustva.

U četvrtom slučaju pacijent nije imao zube u gornjoj čeljusti, a u donjoj su bili slabo poduprti. Unatoč činjenici da je provedeno parodontološko liječenje (kirurško ili nekirurško), očekivala se loša prognoza. Većina doktora $(83,3 \%)$ odlučila je izvaditi sve zube. Oni koji su odlučili očuvati zube, opravdanje su mogli pronaći u načelu bioetičke autonomije (26) koje pacijentu omogućuje sudjelovanje u kliničkom procesu odlučivanja (pacijent je želio zadržati zube). Ozbiljnost parodontne bolesti $(86 \%)$, nedostatak alveolarne kosti $(79,3 \%)$ i loša oralna higijena (60\%), bili su najčešći razlozi za odluku o vađenju. Ti čimbenici, povezani s dobi pacijenta i kliničkim stanjem, mogu opravdati odluku o ekstrakciji.

Kao i u većini anketa na temelju upitnika, ovo istraživanje osmišljeno je da bi simuliralo klinički scenarij s četiri pacijenta kako bi se istražio i ilustrirao proces donošenja odluka u parodontologiji. Buduća istraživanja trebala bi biti strukturirana tako da detaljnije istraže razinu znanja u parodontologiji i njezin utjecaj na odlučivanje o složenijim i detaljnijim kliničkim slučajevima. Uz to, upitnik treba testirati i potvrditi u drugim populacijama kako bi se dobio širi raspon prikupljenih podataka i u budućnosti omogućile populacijski specifične usporedbe.

\section{Zaključak}

Kad je riječ o vađenju zuba, na donošenje kliničkih odluka općih stomatologa i parodontologa utjecali su stupanj parodontne bolesti, razina oralne higijene pacijenta i razina preostale alveolarne kosti.

Kao što se i očekivalo, okolnosti specifične za pojedini slučaj utjecale su na proces donošenja kliničkih odluka, ali su u većini slučajeva parodontolozi bili manje invazivni i češće su odlučivali očuvati zube, uz odgovarajuće terapijsko praćenje.

\section{Sukob interesa}

Autori ne navode sukob interesa. 
Sažetak

Ciljevi: Željelo se istražiti profesionalne aspekte te kliničke i rendgenske pokazatelje koji utječu na odluku parodontologa i općih stomatologa o vađenju zuba. Materijali i metode: Uzorak se sastojao od 150 ( $n=106$ žena i 44 muškarca) doktora dentalne medicine $(n=103$ općih stomatologa i 47 parodontologa) koji su ispunili upitnik osmišljen za prikupljanje presječnih informacija koje se odnose uglavnom na razinu njihove edukacije $\mathrm{i}$ iskustvo u praksi, te na osobnu terapijsku odluku u slučaju četiri pacijenta s parodontnim bolestima. Bivarijantna analiza obavljena je kako bi se testirala povezanost kliničkih odluka i profesionalnih informacija prikupljenih od doktora dentalne medicine. Rezultati: $U$ određenim slučajevima parodontolozi su odlučili sačuvati više zuba od općih stomatologa $(p<0,05)$. U drugima, pak, doktori s višegodišnjim iskustvom u praksi odlučili su se za više ekstrakcija $(p<0,05)$. Stupanj parodontne bolesti $(50-92 \%)$, loša oralna higijena $(42,6-67,3 \%)$ i nedostatak alveolarne kosti (43,2 - 79,3 \%) bili su najčešći razlozi za odluku o vađenju. Zaključak: Viša razina edukacije u dentalnoj medicini, posebno u parodontologiji te višegodišnje iskustvo u praksi mogu utjecati na utemeljenu odluku o vađenju zuba ili o očuvanju u specifičnim slučajevima.
Zaprimljen: 19. studenoga 2018. Prihvaćen: 23. travnja 2019.

Adresa za dopisivanje Rhonan Ferreira Silva Federal University of Goiás Department of Dentistry Av. Universitaria, Esquina com $1^{\text {a }}$ Avenida $\mathrm{s} / \mathrm{n}$ Goiânia, Goias, Brazil tel.: 00556232096051 rhonansilva@gmail.com

Ključne riječi donošenje kliničkih odluka, parodontologija, radiologija, vađenje zuba

\section{References}

1. Kassebaum NJ, Bernabé E, Dahiya M, Bhandari B, Murray CJ, Marcenes W. Global burden of severe periodontitis in 1990-2010: a systematic review and meta-regression. J Dent Res. 2014 Nov;93(11):1045-53.

2. Eke PI, Dye BA, Wei L, Slade GD, Thornton-Evans GO, Borgnakke WS et al. Update on prevalence of periodontitis in adults in the United States: NHANES 2009 to 2012. J Periodontol. 2015 May;86(5):611-22.

3. Rozier RG, White BA, Slade GD. Trends in oral diseases in the U.S. population. J Dent Educ. 2017 Aug;81(8):eS97-eS109.

4. Batista MJ, Lawrence HP, Sousa ML. Tooth loss classification: factors associated with a new classification in an adult population group. Cien Saude Colet. 2015 Sep;20(9):2825-35.

5. Irie K, Tomofuji T, Ekuni D, Morita M, Shimazaki Y, Darveau RP. Impact of oral commensal bacteria on degradation of periodontal connective tissue in mice. J Periodontol. 2015 Jul;86(7):899-905.

6. Goh V, Corbet EF, Leung WK. Impact of dentine hypersensitivity on oral health-related quality of life in individuals receiving supportive periodontal care. J Clin Periodontol. 2016;43(7):595-602.

7. Zitzmann NU, Krastl G, Hecker H, Walter C, Waltimo T, Weiger R. Strategic considerations in treatment planning: Deciding when to treat, extract, or replace a questionable tooth. J Prosthet Dent. 2010 Aug;104(2):80-91.

8. Corbet EF, Ho DK, Lai SM. Radiographs in periodontal disease diagnosis and management. Aust Dent J. 2009;54(Supp 1):27-43.

9. White SC, Pharoah MJ. Oral Radiology - principles and interpretation. 7th ed. Maryland Heights: Mosby Elsevier; 2015.

10. American Academy of Periodontology. Comprehensive periodontal therapy: a statement by the American academy of periodontology. J Periodontol. 2011 Jul;82(7):943-9.

11. Kornman KS, Giannobile WV, Duff GW. Quo vadis: what is the future of periodontics? How will we get there? Periodontology 2000. 2017;75(1):353-71.

12. Bigras BR, Johnson BR, Begole EA, Wenckus CS. Differences in clinical decision making: a comparison between specialists and general dentists. Oral Surg Oral Med Oral Pathol Oral Radiol Endod. 2008 Jul;106(1):139-44.

13. Junges R, Zitzmann NU, Walter C, Rösing CK. Dental care providers' decision making regarding maintenance of compromised teeth and implant therapy indication: an analysis of gender and enrollment in teaching positions. Clin Oral Implants Res. 2014 Sep;25(9):1027-33

14. Hybels CF, Wu B, Landerman LR, Liang J, Bennett JM, Plassman $\mathrm{BL}$. Trends in decayed teeth among middle-aged and older adults in the United States: socioeconomic disparities persist over time. J Pub Health Dent. 2016;76(4):287-94.
15. Zitzmann NU, Scherrer SS, Weiger R, Lang NP, Walter C. Preferences of dental care providers in maintaining compromised teeth in relation to their professional status: implants instead of periodontally involved maxillary molars? Clin Oral Implant Res. 2011;22(2):143-50.

16. Vražić D, Miovski Z, Strozzi M, Puhar I, Badovinac A, Božić D, et al. Periodontal disease and its association with angiographically verified coronary artery disease. Acta Stomatol Croat. 2015;49(1):14-20.

17. Oreški NP, Čelebić A, Petričević N. Assessment of esthetic characteristics of the teeth and surrounding anatomical structures. Acta Stomatol Croat. 2017;51(1):22-32.

18. Lohi HS, Nayak DG, Uppoor AS. Comparative evaluation of the efficacy of bioactive ceramic composite granules alone and in combination with platelet rich fibrin in the treatment of mandibular class II furcation defects: a clinical and radiographic study. J Clin Diag Res. 2017;11(7):76-80.

19. Levin L, Halperin-Sternfeld M. Tooth preservation or implant placement: a systematic review of long-term tooth and implant survival rates. J Am Dent Assoc. 2013;144(10):1119-33.

20. Zeza B, Pilloni A, Tatakis DN, Mariotti A, Di Tanna GL, Mongardini C. Implant patient compliance varies by periodontal treatment history. J Periodontol. 2017;88(9):846-53.

21. Wood WR, Greco GW, McFall WT Jr. Tooth loss in patients with moderate periodontitis after treatment and long-term maintenance care. J Periodontol. 1989;60(9):516-20.

22. Fardal O, Johannessen AC, Linden GJ. Tooth loss during maintenance following periodontal treatment in a periodontal practice in Norway. J Clin Periodontol. 2004 Jul;31(7):550-5.

23. Schwendicke F, Stolpe M, Plaumann A, Graetz C. Cost-effectiveness of regular versus irregular supportive periodontal therapy or tooth removal. J Clin Periodontol. 2016;43(11):940-7.

24. Gupta N, Gupta ND, Goyal L, Moin S, Khan S, Gupta A, et al. The influence of smoking on the levels of matrix metalloproteinase-8 and periodontal parameters in smoker and nonsmoker patients with chronic periodontitis: A clinicobiochemical study. J Oral Biol Craniofac Res. 2016;6(Supp 1):39-43.

25. Coretti L, Cuomo M, Florio E, Palumbo D, Keller S, Pero R, et al. Subgingival dysbiosis in smoker and non-smoker patients with chronic periodontitis. Mol Med Rep. 2017 Apr;15(4):2007-2014.

26. Franco A, Alqerban A, De Lima AAS, Tanaka OM, França BHS. The orthodontist's responsibility and the bioethical aspects in the current jurisprudence. Eur J Gen Dent. 2012;1(1):20-23. NIJE U PUBMEDU 